\title{
FOREIGN INVESTMENT AND THE BRAZILIAN REAL ESTATE MARKET
}

\author{
João da Rocha LIMA Jr. ${ }^{1}$ and Claudio Tavares de ALENCAR ${ }^{2}$ ه \\ ${ }^{1}$ Department of Civil Construction and Engineering, Polytechnic School - University of São \\ Paulo, Av. Prof. Almeida Prado, travessa 2 n. 83. Cidade Universitária-05508-900. \\ São Paulo, Brasil \\ E-mail: rocha.lima@poli.usp.br \\ 2 Department of Civil Construction and Engineering, Polytechnic School - University of São \\ Paulo, Av. Prof. Almeida Prado, travessa 2 n. 83. Cidade Universitária-05508-900. \\ São Paulo, Brasil \\ E-mail: claudio.alencar@poli.usp.br
}

Received 27 April 2007; accepted 10 March 2008

\begin{abstract}
This article discusses the main aspects of the Brazilian real estate market in order to illustrate if it would be attractive for a typical American real estate investor to buy office-building portfolios in Brazil. The article emphasizes: [i] - the regulatory frontiers, comparing investment securitization, using a typical American REIT structure, with the Brazilian solution, using the Fundo de Investimento Imobiliário - FII; [ii] - the investment quality attributes in the Brazilian market, using an office building prototype, and [iii] - the comparison of [risk vs. yield] generated by an investment in the Brazilian market, using a FII, benchmarked against an existing REIT (OFFICE SUB-SECTOR) in the USA market.

We conclude that investing dollars exchanged for Reais [the Brazilian currency] in a FII with a triple A office-building portfolio in the São Paulo marketplace will yield an annual income and a premium return above an American REIT investment. The highly aggressive scenario, along with the strong persistent exchange rate detachment to the IGP-M variations, plus instabilities affecting the generation of income, and even if we adopt a 300-point margin for the Brazil-Risk level, demonstrates that an investment opportunity in the Brazilian market, in the segment we have analyzed, outperforms an equivalent investment in the American market.
\end{abstract}

KEYWORDS: Foreign investments; Brazil; Office market; Currency risk; Monte Carlo simulation

\section{INTRODUCTION}

Funds allocated to investments in real estate businesses tend to be conservative and in general invested based on two determining premises: regular homogeneous income and the expectation of low fluctuations with respect to the value of the real estate. In other words, real estate investments tend to be on average less volatile than other typical assets in capi- tal markets such as stocks, hence the frequent use of these investments to increase stability in the portfolios strategy of diversification.

In less developed economies, these premises may not prevail because, sometimes, even the assets of the real estate market suffer from the impact of market volatility and erratic macroeconomic movements. Such economies tend to jeopardize security concerns that determine investment decisions in real estate. Since the 
$1^{\text {st }}$ and $2^{\text {nd }}$ quarters of 2006 , there has been increased speculation about the migration of foreign investments to the real estate segment of Brazil, mainly to construct office buildings. Nevertheless, even if you consider the current liquidity in the world economy and the natural trend that part of these funds should seek for real estate markets, foreign investors are reluctant to risk investing in this segment of the Brazilian market.

The opportunity for foreign investors to invest in the Brazilian real estate market should be considered keeping in mind the structural aspects we discuss in this article. We also show medium-term projections for São Paulo office market indicators with the purpose of comparing them to those of the United States. Taking into consideration Newell and Webb (1996), Geurts and Jaffe (1996) and Stevenson (2000), we can infer that the aspects to be covered in assessing a foreign investment opportunity to enter a specific economy in the segment of real estate, should include analyses of: [i] - the impact on the economy resulting from the exchange rate for strong currencies and the investment hedging cost, as pointed out by Liu and Mei (1998) and Ziobrowski et al. (1996, 1997); [ii] - regulatory boundaries to understand investor protection; [iii] - the level of liquidity of investments in real estate as permitted by the investment-sharing systems present in the Brazilian economy; [iv] - the strength of the secondary market to measure the possibility of making use of this liquidity; [v] the pattern of available information to interpret the market's behavior and [vi] - the potential return on investments.

Macroeconomic aspects, which involve exchange rates and secondary market hedging, are discussed in general terms. Special attention is given to: [i] - the discussion of regulatory frontiers, comparing a typical REIT structure with the Brazilian FII [Fundo de Investimento Imobilário/Real Estate Investment Fund], which in Brazil is the structure most similar to an American REIT; [ii] - the intrinsic quality of investing in office buildings to let using a portfolio of hypothetical buildings from the Brazilian market and [iii]- the comparison of risk vs. return on foreign investments in Brazilian office buildings to rent via an FII, against the same type of investment in the American market, in an office building REIT.

\section{REAL ESTATE INVESTMENT FUNDS IN BRAZIL}

An FII is the typical structure available in the Brazilian market for investment sharing in real estate, which offers fiscal advantages not found in other forms of securitization in Brazil and whose structure differs from the REITs in the American market, as described in Young (2000) and Ambrose and Linneman (2001). These investment pools focus on the real estate market allocating resources to an investment manager. All the financial operations are regulated by the Rules for Fund Operation, where they are registered and submitted for approval by the CMV [Comissão de Valores Mobiliários/Brazilian Securities Commission], a government agency for regulating capital market operations, which in some ways is similar to the American SEC.

The legal concept of FIIs created some restrictions with respect to real estate maintenance, registration and transactions, as well as to certain business-development activities, which the FIIs are free to carry out. These restrictions were relaxed by Federal Law 8.668 (1993), which governs the creation and operation of the FIIs, and by CVM Instruction 205 (1994), which outlined the FII constitution, operations and management, providing management and operation norms in detail.

Law 8.668 (1993) defined that the operations (buying/selling of assets) and profit sharing of FIIs is tax-free, which was not the case earlier. Under current legislation, private 
investors are exempt as long as they comply with certain rules of distribution such as not owning more than $10 \%$ of the total shares in an FII.

In Brazil, where high taxation can discourage investing, the tax exemptions offered to the FIIs and their investors are so many, and so significant that other real estate-based portfolio securitization solutions end up being ignored, even if they present a more advanced structural design than that of the FIIs. In general, FII shareholders are only taxed after shares have appreciated and been sold at a profit.

Still, under Brazilian legislation, one can set up structures of investment sharing in real estate under concepts equivalent to those of the REIT, using an SPE [Sociedade de Propósito Exclusivo/Sole Purpose Company] as the environment to shelter the portfolio and attracting investors by means of shares of mandatory dividend or perennial result-sharing debentures. However, an SPE must pay a tax on income and earnings, which leaves the investment less attractive than a real estate portfolio sheltered in an FII.

One other important difference between FIIs and the American REIT lies in the legislation covering management: [i] - FIIs must necessarily be under the administration of financial institutions rather than commanded by an entrepreneurial type executive; [ii] the management of SPEs and REITs is in the hands of such individuals, see Young (2000).

This imposition refers to the entrepreneurial skills that such an administrator of SPEs and REITs should have in dealing with real estate transactions whereas, financial institutions, in the view of asset managers, deal with investment products of high liquidity and volatility while also working with investment protection and instruments of hedging. The manager of an FII administers a portfolio having little manager's specialization, which, in real estate deals, should stand out with respect to specialized skills, not to financial management. FII administrators typically manage portfolios having little or no flexibility in that the FII is comprised of a single building. The administration of such a portfolio does not involve the dynamism of a continual change in portfolio positions, but merely requires topical actions and the administration of rental contracts and leases. For example, at BOVESPA [The São Paulo Stock Exchange] one can negotiate shares of an FII, the portfolio of which comprises a single office building leased to Caixa Econômica Federal (a state-owned bank) for 10 years and with the tenant having the option to renew for another 10. In cases like this, the managerial skills required of the administrator comprehend collecting and distributing the monthly rental among the shareholders and renegotiating the price, perhaps every 5 years. The other FIIs listed at BOVESPA do not differ from such rigid patterns: they comprise of fice buildings (one per FII), shopping centers (one per FII), and one of them has a hotel in its portfolio.

Brazil's real estate investment market will only begin to encourage the funding of foreign resources once the securitized formats for investing have more diversified portfolios for leasing and the administrator has the authority to buy, sell, renew and, in general, take advantage of opportunities that strengthen the portfolio.

We must note here that an FII, classified as an investment condominium, is subject to Brazilian legislation forbidding the use of leverage. All investments require positions of $100 \%$ equity.

According to the register of CVM [Brazilian Securities Commission], in September 2007 there were 67 FIIs in existence with each having an average total net asset value of $R \$ 3.03$ million reais (US\$ 1.55 million dollars ${ }^{1}$ ). Most

${ }^{1}$ Using the current exchange rate of 1 US $\$=1.95$ Reais $(\mathrm{R} \$)$ - source: Brazil Central Bank (www.bcb.gov.br) 
of them comprising a single building and registered as funds with a restricted purpose.

The secondary market in Brazil is incipient, the number of FIIs negotiated on the Stock Exchange being 24; these others are restricted to non-regulated markets and are, in reality, private investment funds belonging to private groups. The net asset value of the FIIs at Bovespa represented US $\$ 887$ million in September 2007, or $57.1 \%$ of the FII market value.

In September 2007, NAREIT (2007) had 183 publicly traded REITs registered on the American market, with an approximate market value of US $\$ 438$ billion (Equity Market Capitalization - EMC). Using the EMC as reference, a medium-sized American REIT ${ }^{2}$ represents about 1.6 times the entire FII market.

The value of the real estate investment market represented by the 183 REITs to which investors have access on the American stock exchange is 494 times greater than that of the 24 Brazilian FIIs negotiated at BOVESPA.

Another important aspect of the REIT portfolio concept in comparison with the single building securitization currently used by the FIIs is that the EMC value of a medium-sized REIT on the American market is about 100 times that of the net asset value of a mediumsized FII in Brazil. The small size of FIIs may be a drawback in that their ability to absorb market fluctuations is quite limited whereas, with larger more diversified real estate portfolios, improving one's position by acquisitions or sales in order to increase profits is always a real possibility.

The lack of attention developers have dedicated to the system of attracting funds by way of FIIs may be, in part, responsible for the slow evolution of the Brazilian market. If we

\footnotetext{
${ }^{2}$ In a simplified way, by dividing the EMC for the number of the REITs, only to give a idea of the Brazilian market size in relation to the American one.
}

consider the dimension and value of the REIT EMC which is equivalent to $2.8 \%$ of the American GDP, this relation in Brazil would represent a market potential of $\mathrm{R} \$ 60$ billion, which is nearly 20 times greater than the market's current appraisal. Illustrating the magnitude of this potential is the region of Luiz Berrini Avenue, where the total value of new triple A office buildings does not exceed $\mathrm{R} \$ 6$ billion.

\section{INVESTING IN A PORTFOLIO OF OFFICE BUILDINGS}

To indicate the investment quality of office buildings on the Brazilian market, we will use the following: [i] - let us consider a triple A hypothetical building in the city of São Paulo. In general we can say that the variables (rental values, prices, operational costs and vacancy rates) attributed to the prototype come from public databases and surveys conducted by the Real Estate Research Group of the Polytechnic School of the University of São Paulo; [ii] - we will set up a building portfolio with an expressive investment value (foreign capital), sheltered in an FII, to offer investors the opportunity to sell their shares at Bovespa; [iii] - we will deal with quality indicators which FII shares should have. Later on, we will deal with foreign-investment risks related to exchangerate fluctuations without hedging.

Considering that the investment is made to build a portfolio to be placed on the secondary market by means of FII shares and that this securitization structure is the one that presents the least taxing impact for individual (not corporate) investors, our speculation on investment quality follows the phases shown in Figure 1.

First, we produced analyses on investment quality and then risk analyses for foreign investors in office buildings to lease in the São Paulo marketplace. The two strategies employed: 


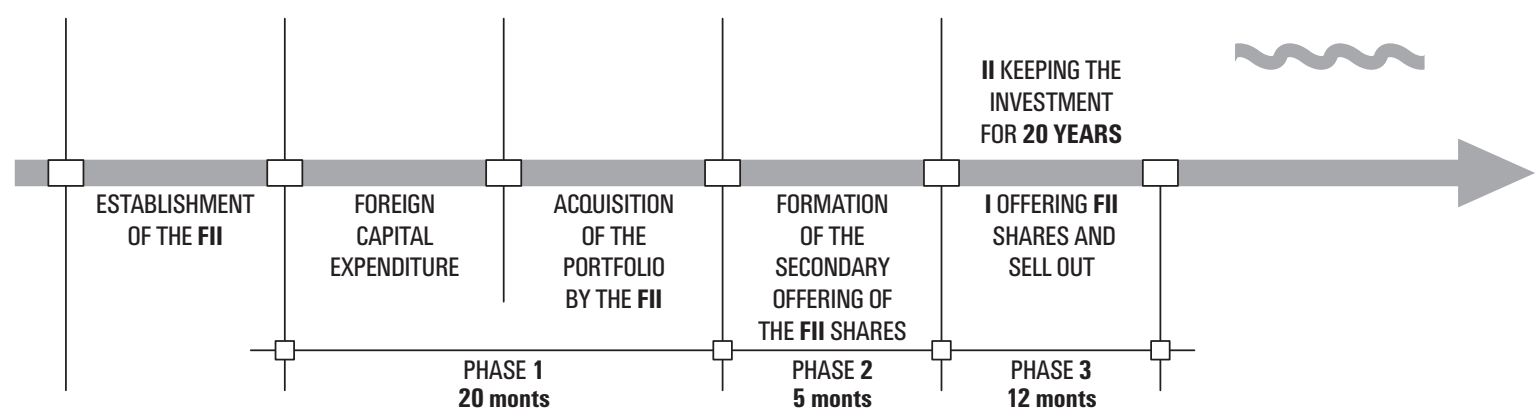

Figure 1. Investment movements, entering the FII and exit strategies I and II

[ I ] - the more aggressive analysis (Figure 1) corresponds to the strategy of looking for the quickest possible exit in which investors develop the portfolio and sell the FII shares to small and medium investors, while leaving management in the hands of a specialized financial institution.

[II ] - the more conservative analysis (Figure1) corresponds to keeping the investment for the entire 20 - year operational cycle.

The first quality analysis is in reais, followed by an evaluation of the risk exchanging the American dollar carries, used as reference for foreign investment. This analysis does not consider any eventual costs in transactions US investors might have if they chose to invest in Brazil.

The portfolio used as reference corresponds to a set of 10 typical triple A buildings containing 10.000 square meters of ABR [Área Bruta Rentável/Gross Leaseable Area - GLA] each, the investment demand for acquisition being $\mathrm{R} \$ 609$ million, including the FII structuring costs.

The referential scenario for the 20-year rental operational cycle comprises the parameters shown in Tables 1, 2 and 3 . We can see that all scenario variables are set within boundaries, in which each variable fluctuates randomly. Considering these limits, the indicators will be presented at intervals, considering laboratory samples, just like in Hughes (1995), constructed from the exploration of multiple scenarios with inflation and exchange rate fluctuations. Actually, we are applying here a Monte Carlo simulation in order to generate confidence intervals for the average of the prototype portfolio's rate of return aiming to compare it with the returns of an American Equity-REIT investment.

Table 1 contains the variables for calculating the expected rental revenue. The scenario

Table 1. Scenario for the operational cycle - rental prices

\begin{tabular}{lcccccc}
\hline & Year 1 & Year 2 & Year 3 & Year 4 & $\begin{array}{l}\text { Year 5 } \\
\text { and so on }\end{array}$ & $\begin{array}{l}\text { Fluctuation } \\
\text { of the revenue }\end{array}$ \\
\hline $\begin{array}{l}\text { Rental prices } \\
\text { in the market }\end{array}$ & 68,00 & 72,00 & 75,00 & 77,00 & 80,00 & \\
$\begin{array}{l}\text { Adjustment } \\
\begin{array}{l}\text { Rental prices } \\
\text { considered for } \\
\text { the prototype }\end{array}\end{array}$ & 0,850 & 0,950 & 1,000 & 1,000 & 1,000 & \\
\hline
\end{tabular}

Rental prices (monthly prices / $\mathrm{m}^{2}$ GLA, in $\mathrm{R} \$$ mar-08) 
contemplates a conservative cycle of market reorganization as well as the market insertion of a likewise conservative portfolio, keeping in mind that there is still a significant amount of vacancy in the market (approximately 15\%) and that the absorption can only take place if the Brazilian economy expands. Following, in the Table 1, are the forecasts for the office market overall performance in relation to Brazilian economic growth.

The boundaries of fluctuation were set up, not only in Table 1 but also in Tables 2 and 3 to allow us to generate lab samples with which to simulate the rate of return volatility as the market's performance changes.

Table 2 presents the occupation rate parameters of a portfolio prototype building and the FII accounts. All cost parameters listed in the table come from the Real Estate Research Group (2006).

The macroeconomic scenario in Table 3 is based on the Brazilian IAER (Institute of Applied Economic Research (www.ipea.gov.br) scenarios for the general Brazilian economy. Two factors affect investment quality: [i] Brazilian reais are affected by inflation and under Brazilian law rental contracts may only suffer re-adjustments annually based on the rate of inflation measured by the general price index, (IGP-M); [ii] - investments in U.S. dollars are submitted to a second loss vector, in that at present, the Real $(\mathrm{R} \$)$ is overvalued against the dollar.

We admit that a certain exchange discrepancy will be compensated for in the next two years and that, from then on, there will be a recurring detachment from the exchange rate to the IGP-M variation. The effects of inflation and persistently increasing exchange rates represent risks for foreign capital investment in Brazilian real estate. For this, there are no hedging mechanisms at accessible costs. The dollar's detachment from the Real places it in the condition of an open risk vector, which we will investigate later.

Table 2. Scenario for the operational cycle - occupation, costs, maintenance and upgrade

\begin{tabular}{|c|c|c|c|c|c|c|}
\hline & Year 1 & Year 2 & Year 3 & Year 4 & $\begin{array}{l}\text { Year } 5 \\
\text { and so on }\end{array}$ & $\begin{array}{l}\text { Factor of } \\
\text { fluctuation } \\
\text { considered }\end{array}$ \\
\hline & \multicolumn{6}{|c|}{ Deterministic scenarios with fluctuations } \\
\hline Market parameters & $65 \%$ & $80 \%$ & $85 \%$ & $87 \%$ & $90 \%$ & \\
\hline $\begin{array}{l}\text { Occupation rate considered } \\
\text { (rented area / GLA) }\end{array}$ & $75 \%$ & $85 \%$ & $95 \%$ & $100 \%$ & $100 \%$ & $\begin{array}{l}-9 \text { points } \\
+0 \text { points }\end{array}$ \\
\hline Market penetration result & 1,154 & 1,063 & 1,118 & 1,150 & 1,112 & \\
\hline $\begin{array}{l}\text { Management costs } \\
\text { of the FII } \\
\text { (\% of the revenue) }\end{array}$ & $6,0 \%$ & & & & & \\
\hline \multirow[t]{2}{*}{ Fluctuation (points) } & +2.0 & +2.0 & +2.0 & +3.0 & +3.0 & \\
\hline & -0.0 & -0.0 & -0.0 & -0.0 & -0.0 & \\
\hline $\begin{array}{l}\text { Vacant spaces cost } \\
\left(\mathrm{R} \$ / \mathrm{m}^{2} \mathrm{GLA} / \text { month }\right)\end{array}$ & 12,80 & & & & & $\begin{array}{l}-5 \% \\
+10 \%\end{array}$ \\
\hline $\begin{array}{l}\text { Maintenance and upgrade } \\
\text { (\% of the revenue) }\end{array}$ & $3,5 \%$ & & & & & \\
\hline
\end{tabular}


Table 3. Scenario for the operational inflation and exchange rate

\begin{tabular}{llllll}
\hline & Year 1 & Year 2 & Year 3 & Year 4 & $\begin{array}{l}\text { Year 5 } \\
\text { and so on }\end{array}$ \\
\hline Annual inflation rate, IGP-M & $6,0 \%$ & $5,5 \%$ & $5,0 \%$ & $5,0 \%$ & $5,0 \%$ \\
Fluctuation (points) & +1.0 & +0.5 & +1.0 & +1.0 & +1.0 \\
& -0.5 & -0.5 & -0.5 & -0.5 & -0.5 \\
Annual rate of detachment & $7,0 \%$ & $7,0 \%$ & $1,0 \%$ & $1,0 \%$ & $1,0 \%$ \\
from the exchange rate & & & & & +1.0 \\
Fluctuation (points) & +1.0 & +1.0 & +1.0 & +1.0 & +0.5 \\
& -2.0 & -2.0 & -0.5 & -0.5 & -0.5 \\
\hline
\end{tabular}

The hurdle rate for small and medium savings perceived in the Brazilian market, seeking income in safe homogeneous real estate flows, is roughly $10 \%$ a year, effective above the IGP-M. See Rocha-Lima and Alencar (2006).

In Table 4, we indicate the value of the FII shares with the aim of identifying foreign investment quality when it chooses an earlier exit (strategy I). The establishment of the share market value is based on the basic case scenario (see Tables 1 and 2) and the imposition of a risk-protection level, reached by con- structing a worse scenario than the referential one (by using the fluctuation limits set up Table 1 and 2).

An analysis of the portfolio behavior during the 20 year operational cycle linked to the referential scenario and the 10\% yearly hurdle rate of return, as in Rocha-Lima and Alencar (2006), revealed that the total present value of the FII shares would be $\mathrm{R} \$ 795,419$ reais, which is equal to $R \$ 1.3061$ reais for each $R \$ 1.00$ share at the time of investment. The total investment value at that time was $R \$ 609,000$ reais.

Table 4. Balance sheet - acquisition, securitization and selling

\begin{tabular}{|c|c|c|c|c|c|}
\hline & & & $\begin{array}{l}\text { Referential } \\
\text { scenario }\end{array}$ & $\begin{array}{l}\text { Hedged } \\
\text { value }\end{array}$ & $\begin{array}{l}\text { Offering } \\
\text { price }\end{array}$ \\
\hline Total of the investment & & 609.000 & & & \\
\hline Acquisition price & 600.000 & & & & \\
\hline Costs for structuring the FII & 9.000 & & & & \\
\hline \multirow[t]{2}{*}{ Value to securitize } & & & 795.419 & 755.763 & 775.787 \\
\hline & & & & $-5,0 \%$ & $-2,5 \%$ \\
\hline Rate of return & & & $10,00 \%$ & $10,58 \%$ & $10,28 \%$ \\
\hline $\begin{array}{l}\text { Offering costs (offering and promotion, } \\
\text { marketing }=4.80 \% \text { ) }\end{array}$ & & & -38.180 & -36.276 & -37.237 \\
\hline \multirow[t]{2}{*}{ Profit } & & & 148.239 & 110.487 & 129.550 \\
\hline & & & & $-25,5 \%$ & $-12,6 \%$ \\
\hline
\end{tabular}

Values in $\mathrm{R} \$$ thousand mar-08 
If we add disturbances within the limits of the scenario described in this analysis, at the mark of $R \$ 755,763$ reais, the share at $R \$ 1.2410$ reais, and in relation to the original value of $R \$ 609,000$ reais, investors would have complete protection against the greatest fluctuation visualized in the scenario. In other words, under the most critical market conditions $^{3}$, one would still be able to obtain in the 20-year cycle, an annual rate of return equivalent to $10 \%$. At this investment value, if the portfolio behaved within the assumptions presented in the basic case scenario with no deviations, the annual rate of return would be $10.58 \%$.

However, the Brazilian market does not necessarily demand such high protection for investments even though the shares may be positioned at higher risks. The placement price can be set for an average rate of return between 10 and $10.58 \%$ per year and included in the prospectus for selling shares. We then use the total worth of the shares, $\$ 775,787$ thousand that is equivalent to $R \$ 1.2739$ for each $\mathrm{R} \$ 1.00$ investment. This produces the result indicated in Table 4 and the investors exit the portfolio leaving the FII to the market.

\section{INVESTMENT QUALITY, IN REAIS}

If the investment in the portfolio is kept for the 20-year operational cycle, the $\mathrm{R} \$ 609,000$ thousand reais investment made in setting up the portfolio (the purchase of real estate and structuring of the FII) would be able to produce an annual FII rate of return of $13.20 \%$. And even with the disturbances brought on from penetrating the market, generating revenue and inflation and with $90 \%$ reliability, the referential scenario still indicates the rate of return for the FII account would not drop below 12,55\%. Figure 2 illustrates a laboratory

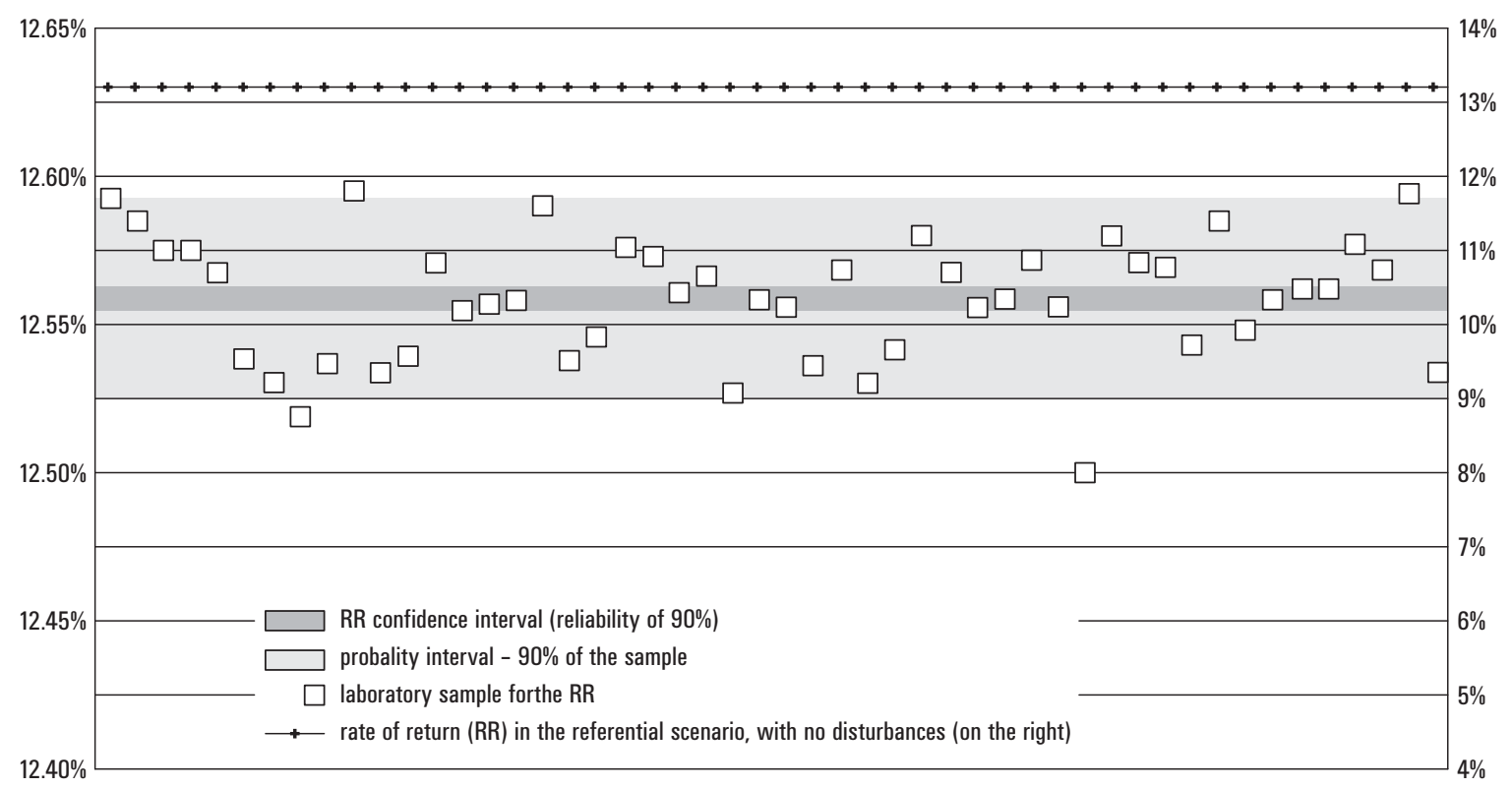

Figure 2. A laboratory sample for the rate of return of foreign investment keeping the portfolio for 20 years, in Reais

\footnotetext{
${ }^{3}$ By using a Monte Carlo simulation approach and considering the lowest confidence interval border of the sample.
} 


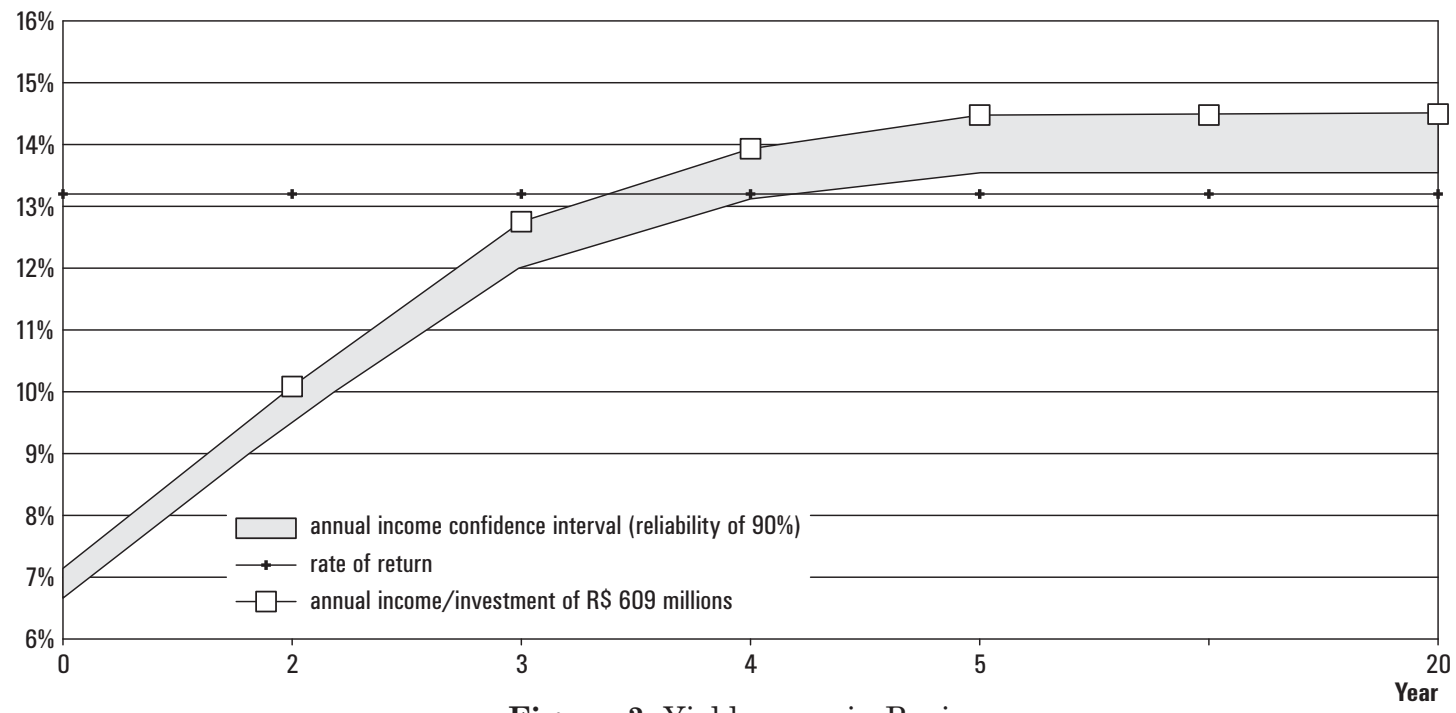

Figure 3. Yield curve, in Reais

sample for this rate of return, obtained with a Monte Carlo approach, showing the boundaries of the confidence interval on the average, when isolated behavior disturbances are made to occur in each of the portfolio buildings ${ }^{4}$.

The investment in this portfolio, kept for 20 years, would present an annual income rate as shown in Figure 3.

In the event that an investor decides to sell his FII shares on the secondary market, at the scenario price, and [i] - the ten-prototype building portfolio is set up in 20 months, [ii] - it takes 5 months to structure and register the share sale in the CVM and [iii] - the share sale is liquidated in 12 months; we will have more favorable indicators concerning investment quality. Using the parameters of the referential scenario, the annual rate of return on investment would be $19.67 \%$ for an investment cycle of 37 months, with the break-even point in the $33^{\text {rd }}$ (thirty-third) month. Although these assumptions may appear somewhat unrealistic due to the nonexistence of a secondary market for FII shares in Brazil, we think it

\footnotetext{
${ }^{4}$ For the proposals of this study, we assumed that the Monte Carlo simulation is sufficient to evaluate risks.
}

is important to show what the rate of return would be for the investor if it were possible to sell the shares and exit the investment in a shorter period.

\section{INVESTMENT QUALITY, IN US DOLLARS}

As we mentioned before, the Brazilian capital market does not offer hedging mechanisms at acceptable costs for medium and long-term investments. Moreover, along with the high cost of setting up the hedging mechanisms that do exist, they suffer heavy taxation which increases the costs even further, and neither are they totally safe, bringing with them a certain amount of risk. Consequently, any real estate investment in Brazil would be subject to risks resulting from the exchange rate.

We have demonstrated that the attractiveness rates perceived in the Brazilian market for foreign investors in prime office buildings are significantly higher than are those in their home markets, Chua (1999). Even so, foreign investors should compare the margins of profit obtained from doing business in a developed economy with those that the Brazilian market 
Table 5. Investment quality indicators - rate of return according to different strategies

Performance according to the referential scenario, without disturbances

Strategy I

(enter and exit),

37 months period
Strategy II

(stay),

20 years period

\section{Rate of return, \% annual}

Nominal in US\$, without detachment

$19,67 \%$

$13,20 \%$

at the exchange rate

Nominal in US\$, with detachment

at the exchange rate

$13,93 \% \quad 11,10 \%$

Strategy I - invest, set up the FII and exit the investment;

Strategy II - invest, set up the FII and stay, receiving the income.

feasibly offers to evaluate the risk/benefit quotient.

As long as the exchange rate variation remains linked to the rate of inflation as measured by the IGP-M the rates of return expressed in US dollars will be the same as those mentioned in item 4. This can serve as strategy to remain in the portfolio for the 20-year cycle or for setting up the portfolio and liquidating the FII share positions before the cycle has ended.
Nonetheless, according to the scenario parameters described in Table 3 , in the event the exchange rate is no longer linked to the IGP-M variation, the rates of return will drop to the levels indicated in Table 5.

A permanent detachment from the exchange rate, as we described in Table 3 , indicates annual income will trend in a downward-sloping curve during the 20 years of the operational cycle, fulfilling the strategy of remaining in the portfolio (Figure 4).

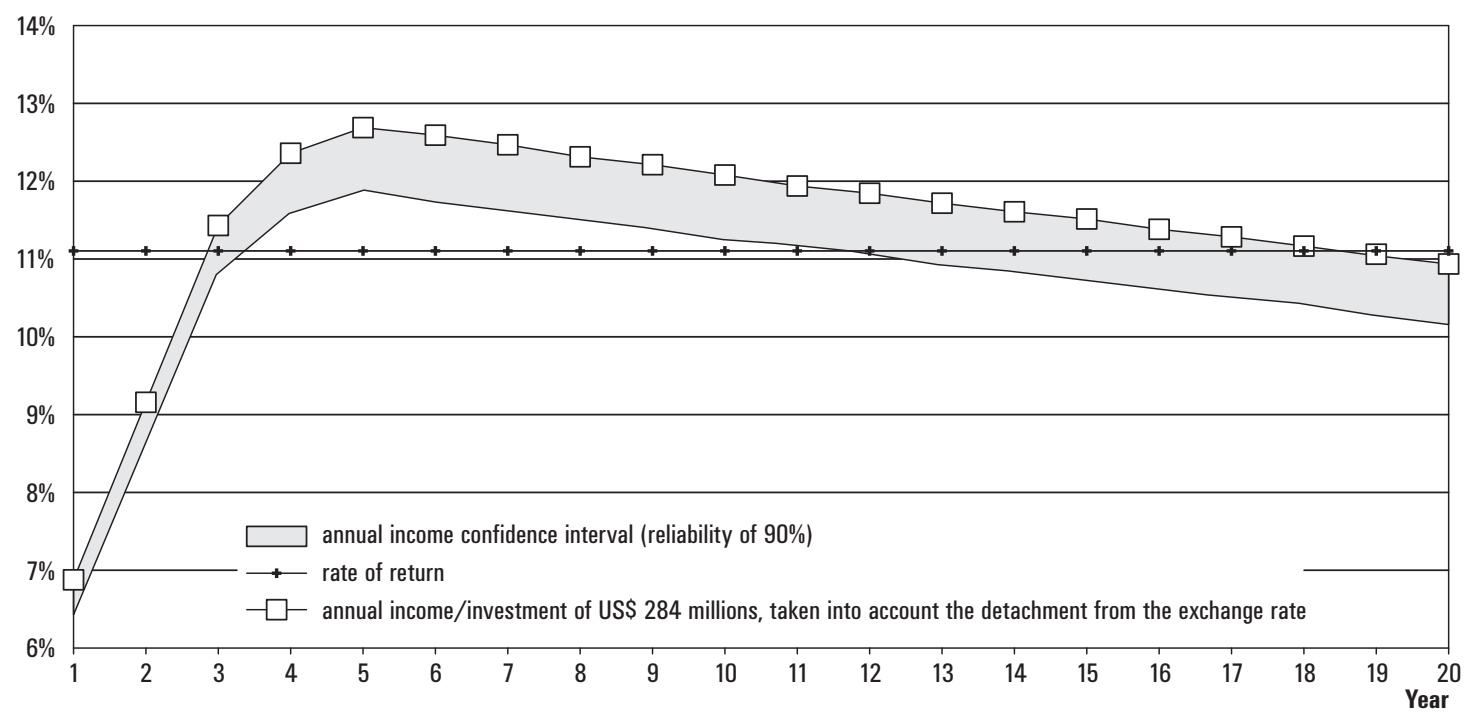

Figure 4. Yield curve, in US dollars with exchange rate detachment 


\section{DISTURBANCE IMPACT - RISK ANALYSIS}

By simulating the portfolio behavior to market risks, along with the inflation rate and operational management cost fluctuations, we can build measurable lab samples with a certain degree of reliability. As mentioned before, these bands of quality indicators or confidence levels indicate the degree of risk for investing in such Brazilian real estate portfolios.

Concerning foreign investments, which are unprotected from exchange hedging, we must still analyze the contingent severance from the exchange rate with respect to the inflation variations of Brazilian currency.

The simulations can lead to the production of different lab samples suitable for analysis from these risks, which in turn allow us to present, in Table 6, how the rate of return indicator fluctuates.

Now, we record the expected financial return, keeping in line with the two border strategies for making foreign investments: [ I ] exiting as early as possible through the sale of the FII shares after the portfolio has been set up or [ II ] - exiting later, at the end of the 20-year operational cycle.

The rates of return with behavior disturbances show border positions (in Table 6 we show the average reliance interval taken from laboratory samples) with a certain detachment, but significantly above the hurdle rate perceived in the Brazilian market, and surely, much higher than the rates that you can receive from the American REIT market, used as benchmark.

Table 6. Investment quality indicators - rate of return and pay back according to different strategies

Performance according to the referential scenario, with and without disturbances

\begin{tabular}{|c|c|c|c|c|c|}
\hline & & \multicolumn{2}{|c|}{$\begin{array}{l}\text { Strategy I } \\
\text { (enter and exit), } \\
37 \text { months period }\end{array}$} & \multicolumn{2}{|c|}{$\begin{array}{l}\text { Strategy II } \\
\text { (stay), } \\
20 \text { years period }\end{array}$} \\
\hline Rate of return & & \multicolumn{4}{|c|}{$\%$ a year } \\
\hline \multirow[t]{2}{*}{ Effective, measured in Reais } & $n$ & \multicolumn{2}{|c|}{$19,67 \%$} & \multicolumn{2}{|c|}{$13,20 \%$} \\
\hline & $y$ (income generation) & $19,28 \%$ & $19,31 \%$ & $12,55 \%$ & $12,56 \%$ \\
\hline \multirow{4}{*}{$\begin{array}{l}\text { Nominal in US } \$ \text {, with exchange } \\
\text { rate detachment }\end{array}$} & $n$ & \multicolumn{2}{|c|}{$13,93 \%$} & \multicolumn{2}{|c|}{$11,10 \%$} \\
\hline & $y$ (income generation) & $13,57 \%$ & $13,60 \%$ & $10,49 \%$ & $10,50 \%$ \\
\hline & $y$ (exchange rate) & $14,17 \%$ & $14,25 \%$ & $10,96 \%$ & $11,10 \%$ \\
\hline & $y$ (combined effects) & $13,81 \%$ & $13,88 \%$ & $10,38 \%$ & $10,44 \%$ \\
\hline \multirow{2}{*}{$\begin{array}{l}\text { Nominal in US } \$ \text {, without exchange } \\
\text { rate detachment }\end{array}$} & $n$ & \multicolumn{2}{|c|}{$19,67 \%$} & \multicolumn{2}{|c|}{$13,20 \%$} \\
\hline & $y$ (income generation) & $19,28 \%$ & $19,31 \%$ & $12,55 \%$ & $12,56 \%$ \\
\hline \multicolumn{2}{|l|}{ Pay back } & \multicolumn{2}{|l|}{ Month } & \multicolumn{2}{|l|}{ Year } \\
\hline \multicolumn{2}{|c|}{ Investment measured in Reais } & \multicolumn{2}{|l|}{33} & \multicolumn{2}{|l|}{8} \\
\hline \multicolumn{2}{|c|}{ Investment measured in US $\$$, with detachment } & \multicolumn{2}{|l|}{34} & \multicolumn{2}{|l|}{9} \\
\hline \multicolumn{2}{|c|}{ Investment measured in US $\$$, without detachment } & \multicolumn{2}{|l|}{33} & \multicolumn{2}{|l|}{8} \\
\hline
\end{tabular}

Scenario without disturbance (n); Scenario with disturbance $(y)$ 
Table 7. Investment quality indicators - annual yield according to strategy II

Performance according to the referential scenario, with and without disturbances

\begin{tabular}{llll}
\hline & $\begin{array}{l}\text { Referential } \\
\text { scenario }\end{array}$ & \multicolumn{2}{l}{ With disturbances } \\
\cline { 3 - 3 } & & on the income & $\begin{array}{c}\text { on the income } \\
\text { and exchange }\end{array}$ \\
\hline Yield - investment in Reais & & \\
$\quad$ Year 1 & $7,15 \%$ & $6,70 \%$ & \\
$\quad$ Year 5 & $14,49 \%$ & $13,56 \%$ & \\
$\quad$ Average of 20 years & $14,14 \%$ & $13,42 \%$ & $6,58 \%$ \\
Yield - investment in US\$, with detachment & & & $12,04 \%$ \\
$\quad$ Year 1 & $6,91 \%$ & $6,48 \%$ & $10,64 \%$ \\
$\quad$ Year 5 & $12,71 \%$ & $11,89 \%$ & \\
$\quad$ Average of 20 years & $11,44 \%$ & $10,85 \%$ & \\
\hline
\end{tabular}

Following strategy II, maintaining the investment for the 20-year operational cycle, the annual income behaves according to the patterns in Table 7.

\section{COMPARATIVE ANALYSIS}

In Figure 5 we show the parameters found in this analysis and the average performance demonstrated by the NAREIT (2007), equiva- lent to the annual dividend yield received by Office Equity REITs in the 1999-2007 (until August) cycle. Using this cycle as a reference we can see that the average income of Office Equity-REITs has fallen. Therefore, instead of taking the average income curve as a reference, we chose two references, the average annual income cycle and the rate of return for investors who entered and exited their positions within the cycle, thus creating a more

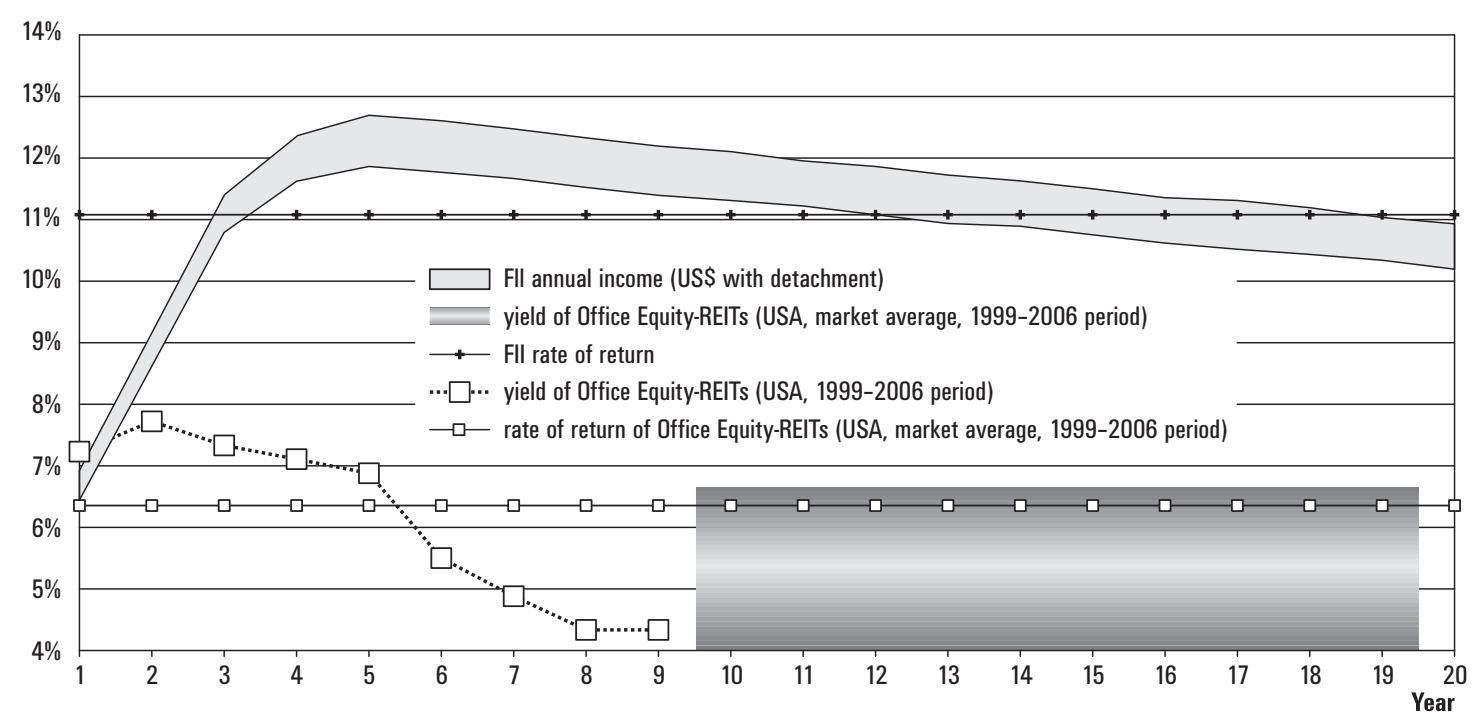

Figure 5. Yield curve and rate of return, in US dollars with exchange rate detachment and equity-REIT market indicators 
aggressive image. That resulted in an average annual nominal income in U.S. dollars of $6.70 \%{ }^{5}$ and the rate of return, $6.37 \%$ observe the Figure 5.

An investment, in U.S. dollars exchanged for Brazilian reais, in an FII with a triple A office-building portfolio in the São Paulo real estate market, even with the exchange rate unprotected by the IGP-M and the devaluation of the dollar, still yields an annual income and rate of return on investment that far exceeds those found in the U.S. market. We have not taken under consideration whether or not, with the detachment, the investor would consider this investment and the risks that come with it, worthwhile. That, in view of the Brazilian risk index and the risks associated with the migration of funds from a developed economy to a developing one. This includes taxation and aspects concerning liquidity. The obvious reward, in the event of an affirmative response to this question, is an FII and its average profitability against that of the American Equity REITs, presented in Table 8.

\section{CONCLUSION}

The objective has been to visualize the amount of foreign interest there might be for investing in the Brazilian real estate market. To do this we have compared indicators taken from behaviour assessment of an FII prototype in the Brazilian market with those of Equity REITs in the United States.

According to our analysis, there are two basic opportunities for foreign investment in the Brazilian real estate sector: [I] - Strategy I - an intermediate-term investment and [II] - Strategy II, staying in the investment for a long (20 years) operational cycle, while earning revenue. There is yet, a third alternative, where the investor can remain on the alert for an opportunity to exit later, before the projected end of cycle. This can occur when the exchange rate variables and the referential interest rate permit financial results above that of the income generated by the portfolio.

In even more aggressive scenarios, in the segment we analyzed, investment opportuni-

Table 8. Investment quality indicators - Brazilian FII versus the NAREIT indexes

\begin{tabular}{|c|c|c|c|c|c|c|}
\hline \multicolumn{7}{|c|}{ FII performance according to the referential scenario, with and without disturbances } \\
\hline & \multirow{2}{*}{$\begin{array}{l}\text { Office } \\
\text { equity } \\
\text { REIT USA, } \\
\text { 1996-2006 }\end{array}$} & \multicolumn{2}{|c|}{$\begin{array}{l}\text { Analyzed FII rates in the } \\
\text { Brazilian market }\end{array}$} & \multirow{2}{*}{$\begin{array}{l}\text { Brazil } \\
\text { risk } \\
(300 \\
\text { points })\end{array}$} & \multicolumn{2}{|c|}{$\begin{array}{l}\text { Analyzed FII rates } \\
\text { discounting Brazil-risk }\end{array}$} \\
\hline & & $\begin{array}{l}\text { with } \\
\text { exchange } \\
\text { detachment }\end{array}$ & $\begin{array}{l}\text { without } \\
\text { exchange } \\
\text { detachment }\end{array}$ & & $\begin{array}{l}\text { with } \\
\text { exchange } \\
\text { detachment }\end{array}$ & $\begin{array}{l}\text { without } \\
\text { exchange } \\
\text { detachment }\end{array}$ \\
\hline \multicolumn{7}{|c|}{ Performance according to the referential scenario } \\
\hline Annual yield & $6,70 \%$ & $11,44 \%$ & $13,79 \%$ & $-3,00 \%$ & $8,44 \%$ & $10,79 \%$ \\
\hline Implicit rate of return & $6,37 \%$ & $11,10 \%$ & $13,20 \%$ & $-3,00 \%$ & $8,10 \%$ & $10,20 \%$ \\
\hline \multicolumn{7}{|c|}{ Income generation and exchange rate disturbances } \\
\hline Annual yield & $6,70 \%$ & $10,64 \%$ & $13,12 \%$ & $-3,00 \%$ & $7,64 \%$ & $10,12 \%$ \\
\hline Implicit rate of return & $6,37 \%$ & $10,38 \%$ & $12,55 \%$ & $-3,00 \%$ & $7,38 \%$ & $9,55 \%$ \\
\hline
\end{tabular}

Nominal rates (\% a year), in US\$

\footnotetext{
5 This rate is even higher than the superior border of the confidence interval obtained in a Monte Carlo approach when applied to the Office REITs historic performance.
} 
ties in the Brazilian real estate market outperform equivalent investments in the U.S. market. Hostile factors include a strong persistent devaluation of the U.S. dollar, exchange rate detachment from the IGP-M variations and disturbances in income generation. In addition, further exemplifying this investment opportunity, we even adopted a 300-point margin for the Brazilian-risk index and still the Brazilian FIIs outperformed Equity REITs in each case scenario.

The income fluctuations, displayed in Table 8 , should be understood as the most depressed hypothesis ${ }^{6}$, with a $7.64 \%$ annual yield in the FII against $6.70 \%$ from the Office Equity REIT-USA, and a $7.38 \%$ rate of return for investments in the FII against $6.39 \%$ obtained from Office REITs, as we see in Table 8. Even within these limits, there is a competitive advantage in the Brazilian market compared to that in the U.S., using the investment in an Office Equity REIT as benchmark.

\section{REFERENCES}

Ambrose, B.W. and Linneman, P. (2001) REIT organizational structure and operating characteristics, Journal of Real Estate Research, 21(3), pp. 141-162.

Chua, A. (1999) The role of international real estate in global mixed-asset investment portfolios, Journal of Real Estate Portfolio Management, 5(2), pp. 129-137.

Geurts, T.G. and Jaffe, A.J. (1996) Risk and real estate investment: An international perspective, Journal of Real Estate Research, 11(2), pp. 117-129.

Hughes, W.T. (1995) Risk analysis and asset valuation: A Monte Carlo simulation using stochastic rents, Journal of Real Estate Finance and Economics, 11(2), pp. 177-187.

\footnotetext{
${ }^{6}$ Obtained by a Monte Carlo approach, considering the lowest confidence interval border of the sample of both, yield and rate of return, when fluctuations are made to income generation and exchange rate in each building of the portfolio.
}

Instruction 205 [INSTRUÇÃO] (1994) Comissão de Valores Mobiliários - CVM, [January, 1994]. Printed publication and electronic one available at: <http://www.cvm.gov.br> [accessed in April 2006]

Law 8.666 [LAW 8.666] (1993) Comissão de Valores Mobiliários [Brazilian Securities Commission] - CVM, junho [June] 1993. Printed publication and electronic one available at: <http://www. cvm.gov.br> [accessed in April 2006]

Liu, C.H. and Mei, J. (1998) The predictability of international real estate markets, exchange rate risks and diversification consequences, Real Estate Economics, 26(1), pp. 3-19.

NAREIT (2007) National Association of Real Estate Investment Trusts, March 2007. Printed publication and electronic one available at: $<$ http://www.nareit.org $>$ [accessed in September 2007]

Newell, G. and Webb, J.R. (1996) Assessing risk for international real estate investments, Journal of Real Estate Research, 11(2), pp. 103-115.

Real Estate Research Group (2006). Development of a GIS Data Base for the São Paulo Real Estate Market - Focus on Office Buildings. Printed publication in July 2006.

Rocha-Lima, J. and Alencar, C.T. (2006). The office buildings market in São Paulo: Time cycles to absorb vacant space and to recover investment attractiveness according to the Brazilian macroeconomic performance, Journal of Financial Management of Property and Construction, 11(1), pp. 59-71.

Stevenson, S. (2000) International real estate diversification: Empirical tests using hedged indices, Journal of Real Estate Research, 19(1), pp. 105-131.

Young, M.S. (2000) REIT property-type sector integration, Journal of Real Estate Research, 19(1), pp. 3-21.

Ziobrowski, A.J., Ziobrowski, B.J. and Rosenberg, S.B. (1997) Currency swaps and international real estate investment, Real Estate Economics, 25(2), pp. 223-251.

Ziobrowski, A.J., McAlum, H. and Ziobrowski, B.J. (1996) Taxes and foreign real estate investment, Journal of Real Estate Research, 11(2), pp. 197-213. 


\section{SANTRAUKA}

\section{UŽSIENIO INVESTICIJOS IR BRAZILIJOS NEKILNOJAMOJO TURTO RINKA}

\section{João da Rocha LIMA Jr., Claudio Tavares de ALENCAR}

Šiame straipsnyje aptariami pagrindiniai Brazilijos nekilnojamojo turto rinkos aspektai, siekiant nustatyti, ar tipinis Amerikos nekilnojamojo turto investuotojas norètu įsigyti Brazilijos biurų pastatų portfelį. Straipsnyje akcentuojama: 1 - kontrolès ribos, lyginant investavima, kai paskolos paverčiamos vertybiniais popieriais, būdingoje Amerikos nekilnojamojo turto fondo (REIT) struktūroje su Brazilijos sprendimu pagal Fundo de Investimento Imobiliário (FII); 2 - investicijų kokybès bruožai Brazilijos rinkoje pagal biurų pastato prototipa; 3 - investicijų i Brazilijos rinką per FII (rizikos ir pelningumo) lyginimas sugretinus su veikiančia REIT (biuru sektorius) JAV rinkoje. Darome išvada, kad investiciniai doleriai, FII iškeisti į realus (Brazilijos valiuta) su „Triple A“ biuru pastato portfeliu, San Paulo rinkoje duos metines pajamas ir papildoma grąža, didesnę už Amerikos REIT investicija. Kai scenarijus itin agresyvus ir vyraujantis kursas atskiriamas nuo rinkos kainų bendrojo indekso (IGP-M) svyravimu, pajamos generuojamos nestabiliai, ir imama 300 tašku rizikos lygio Brazilijoje marža, matome, kad mūsų analizuotame segmente investicijos Brazilijos rinkoje duoda geresnius rezultatus nei analogiška investicija Amerikos rinkoje. 